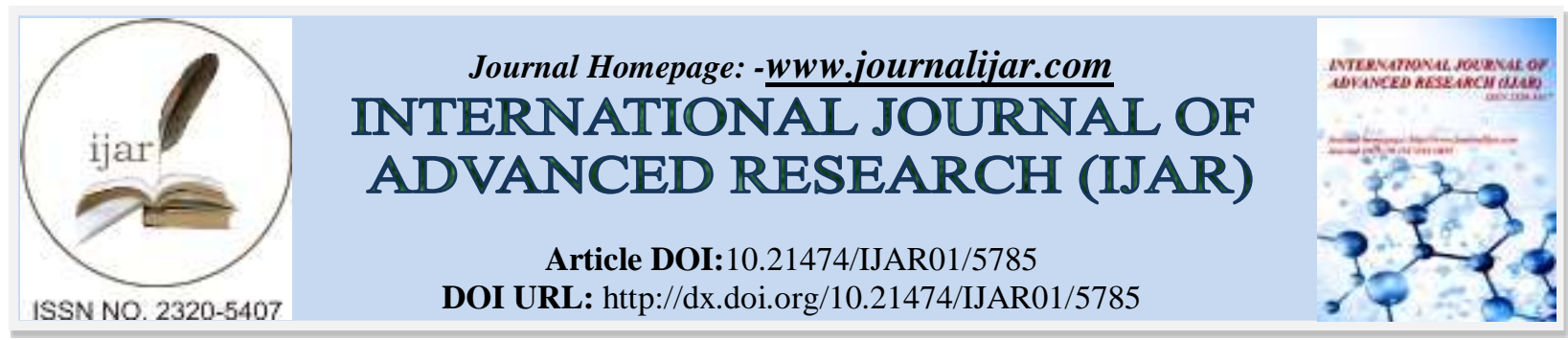

RESEARCH ARTICLE

\title{
ECONOMICAL-ECOLOGICAL ASPECTS OF COMPLEX USE OF ALUMINUM RAW MATERIAL IN AZERBAIJAN.
}

Afandiyeva Z. J.

Assistant professor, candidate of technical sciences (Azerbaijan State Oil and Industry University).

\section{Manuscript Info}

\section{Manuscript History}

Received: 06 September 2017

Final Accepted: 08 October 2017

Published: November 2017

Key words:-

technology of alunite, initial enrichment, waste processing, chemical elements, burning sulfur, sulfur and sulfuric.

\section{Abstract}

The paper deals with economical-ecological recommendations on the complex use of the Zaghlik alunite deposit.

Currently, reconstruction of Ganja Aluminum plant on the basis of new machinery and technology is fully completed, taking into account the complex use of alunite ore and waste to protect the environment.

However, due to the absence of the concentrator at Zaghlik deposit, half of the crushed ore consists of impurities of non-aluminate minerals (kaolinite, pyrophyllite and quartz), the transportation of which entails large transport costs and complicates the chosen production technology at this plant.

Therefore, we suppose that, it is necessary to perform the first enrichment of the alunite ore at the deposit in order to improve the technology of alunite production at the plant. We propose to build a concentration plant at Zaghlik deposit to separate minerals of impurities from alunite. At the same time, the resulting waste of enrichment can be used as raw material for the porcelain-faience industry. The implementation of this recommendation will reduce the volume of raw ore by half and will provide significant savings in the transportation and processing of alunite concentrate.

High economic efficiency of this process is that, enriched ore having a high content (from $88 \%$ to $93 \%$ ) of alunite with high recovery (from $75 \%$ to $78 \%$ ) of alumina can contribute to the improvement of production and technological operations, to a minimum waste and prevention of environmental pollution causes.

Copy Right, IJAR, 2017,. All rights reserved.

\section{Introduction:-}

Currently, the priority object of non-ferrous metallurgy raw materials in Azerbaijan is Zaghlik alunite deposit, Paragachay molybdenum deposit and Filizchay group of deposits of sulfide-polymetallic ores.

After the collapse of the USSR and the independence of Azerbaijan the development of the first two deposits of colored ores was completely suspended because of unfavorable socio-economic conditions. Meanwhile, the mineral and raw materials base of non-ferrous metallurgy in Azerbaijan is not exhausted by these deposits.

Corresponding Author:-Afandiyeva Z. J.

Address:-Assistant professor, candidate of technical sciences (Azerbaijan State Oil and Industry 
Significant resources of polymetallic ores in the Republic are located in Filizchay and Nakhichevan groups and the Mekhmanin deposit in Nagorno-Karabakh. The ore of these deposits contains several dozens of useful components, the majority of which can be extracted at this level of contemporary technology.

The Filizchay group of deposits of sulfide-polymetallic ores is unique both in reserves and favorable mining conditions and in the concentration of accompanying elements. Four deposits of sulfide-polymetallic ores belong to this group: Filizchay, Kotekhchay, Katsdagh, and Tenross.

\section{Mineral resources of the region:-}

Above mentioned deposits are located in a picturesque mountainous area of the Balakan and Zagatala regions. (Geology of Azerbaijan, 2003, Mineral resources of Azerbaijan, 2005, Geology and Mineral Resources of Azerbaijan, 2000). While these deposits are being developed, green mountain ranges, populated areas and mountain rivers may be under threat of destruction due to mass pollution of the environment with sulfuric anhydride and other macro and microelements contained in ore concentrate.

In addition, the production of concentrates with subsequent processing in other plants of foreign countries contradicts the principle of complex processing, as it excludes the use of waste and the production of pyrite concentrate.

Processing of polymetallic ores in conditions of imperfect technology can lead to the loss of a large number of useful components from 1 ton of raw materials, which is inadmissible in case of acute need of polymetallic resources of Azerbaijan in the international market (Afandiyeva, 2017)

On the base of the interests of environmental protection and a number of economic factors of the most advantageous place for the dislocation of the Filizchay mining complex, we propose, Dashuz steppe area, near which there are almost no settlements and green areas, agricultural crops. The site is located near the railway junction of Yevlakh, Mingechaur, Sheki, Zagatala, Gakh, where a large number of labor resources are concentrated, a large part of which may be involved in the mentioned production (Khalifazada and Mamedov,2011).

This site is also advantageous thanks to its reserves of economic, technological and drinking water, a natural closed "tailing dump" (Ajinor lake), in summer it turns into a dead valley. It can be used as a natural waste storage facility of the plant with a full metallurgical cycle. In addition to a mining plant, there is a chemical plant for producing elemental sulfur and sulfuric acid from the pyrite concentrate, and copper powder from copper concentrate (or copper sulfate).

We propose to build a mineral-raw material complex (MRC) with the appropriate infrastructure. Moreover, we propose to build a repair and mechanical plant for repairing the machines and equipment of the mining plant next to the metallurgical combine, as well as enterprises producing agricultural and transport vehicles.

Repeated and combined use of polymetallic ores is of paramount importance in the complex use of mineral raw materials, waste utilization and environmental protection, which doubles the specific weight of extracted components in comparison with the isolated method (Nabiyev 1978, Chanturia, 1995, Larichkin, 2000).

Recycling of waste, sludge, slag, wastes sulfur-containing and other gases, dusts and waste materials is the most important factor in the scientifically based organization of the mining and metallurgical production cycle, expansion of the raw material base and economical use (resource saving) of mineral raw materials ( Nevskaya, 2013, Knysh and Nevskaya , 2015,. Krasnov and Salikhov, 2014).

Such a way to the development of mineral resources provides additional production of non-ferrous metals, chemical, agrochemical, construction, glass raw materials.

Reducing metal, chemical and building raw materials losses significantly increases the yield coefficient of useful components and contributes to the improvement of the environment. The more the coefficient of complex use of ore raw materials, the less are production waste, and, consequently, pollution of the environment (Trubetski et al, 2003, Pevzner, 2001, Afandiyeva, 2014). 
In Azerbaijan the main raw material for the production of aluminum (alumina) is the alunite ore of Zaghlik deposit (Fig. 1). It is a complex raw material for the production of aluminum, sulfuric acid, potassium sulfate, vanadium, agrochemical and building materials. In addition to the main component of alunite, alunite ore contains a significant amount of other useful components. The main component of ore is alunite alumina (51\%) (Gashgay, 1970). The aluminum plant was put into operation in Ganja in 1965 on the base of Zaghlik alunite, which was partially suspended in 1991 based on socio-economic and environmental considerations.

Currently, the reconstruction of Ganja Aluminum plant is being completed fully on the basis of new machinery and technology, taking into account the complex use of alunite ore and waste for environmental protection.

In the absence of a concentrator, half crushed ore deposit consists of non-alunite raw materials which, entail large transport costs and complicate the production technology at this plant during transportation.

Therefore, the most important measure is primarily enriching initial alunite ore in order to improve the production technology of alunite at the plant.

The calculations carried out on the base of materials from other existing enterprises show that, capital expenditures for enriching 1 ton of ore, assuming the cost of initial ore as zero, averages \$ 5.05 (US). Hence, the total cost of enriching the given amount of alunite is $\$ 15$ million. Enriching ore reduces the volume of ore almost by half and provides significant savings, during transportation and processing. Wastes of quartz sands, glass, construction and agrochemical raw materials enrichment can be successfully used in the relevant industries.

Initial enrichment of alunite ore is firstly directed to the complex use of raw materials, reduction of transportation from the deposit to the plant. The improvement of ore processing prevents environment pollution around Ganja.

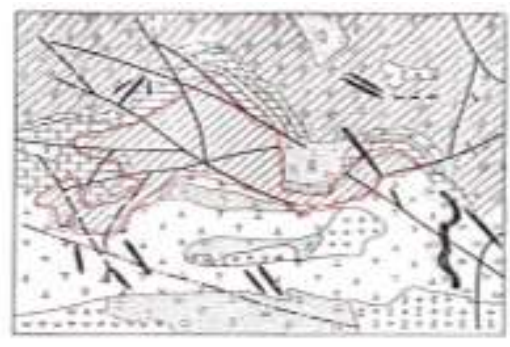

Fig. 1:- Geological map of Zaghlik deposit of alunite

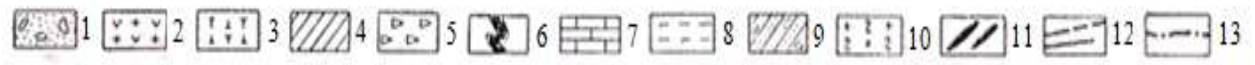

1- alluvial, elluvial and delluvial formations (Q); 2-diabase porphyry (K-J $\left.\mathrm{J}_{1}\right)$; 3- upper suite - tuffs and tuffites (J3 $\mathrm{km})$; 4-lower suite - alunite stratum $\left(\mathrm{J}_{3} \mathrm{Ox}\right)$; 5-hornstones $\left(\mathrm{J}_{2}-\mathrm{J}_{3} \mathrm{Ox}-\mathrm{km}\right) ; 6$ - skarn iron ore deposit; 7 - CampaignMaastricht limestone (J3ox-km); 8 - argillite and sandstones with inter-beds of marls (J3kl); 9-porphyrites (J2); 10 gabbro and granitoids; 11 - dikes of vein-rock; 12- lines of tectonic ruptures; 13 - occurrence element

In addition to aluminum raw materials, Zaghlik alunite contains a number of useful components (Afandiyeva, 2016). Such important chemical elements as pentoxide vanadium, titanium, gallium, sodium sulfate, glass, construction, agrochemical raw materials contained in alunite are not extracted, but they go to dumps occupying huge land.

In addition, alunite ore also contains a large amount of sulfur. While processing alunite in alumina, sulfur and its compounds become volatile gas, most of which resulting from factory pipes. In the form of anhydride, sulfur is contained in the waste gases of the plant.

Trapping sulfur and sulfur-containing elements from volatile gases will significantly meet the gap of the republic in sulfuric acid. In the production of sulfuric acid, sulfur has a great advantage over other sulfur-containing components, both during transportation and processing technology. The process of burning sulfur is much more effective than burning sulfur pyrite, the cost of transporting sulfur is 2.5 times cheaper than pyrites and 3 times cheaper than sulfuric acid. 
Experiments of many enterprises in the USA, Canada and Mexico confirm the expediency of obtaining sulfur from sulfur-containing gases (Bradley and Sharpe, 2009).

Wastes are divided into solid, liquid and gaseous products at the enterprises of non-ferrous metallurgy of the republic. These waste products cause great harm to the environment. The dusts accompanying the production and the gases of mining enterprises are irrecoverable waste. They dissolve in the air, causing the pollution of the atmosphere. In this context, special attention should be paid to the processing of gaseous dust, which will increase the extraction of minerals and the complex use of mineral raw materials.

The use of contemporary dust collectors and electrostatic precipitators in Ganja clay-earth plant enables to obtain additionally hundreds of tons of alumina, sulfuric acid, calcium sulfate, and so on. The production of sulfuric acid from the gases of kilns significantly reduces the technological cycles, reduces operating costs compared with obtaining it from the original mineral raw materials.

Sulfur gases yielding from Ganja plant are also a valuable raw material for the production of elemental sulfur and liquid sulfuric anhydride, being more transportable than sulfuric acid.

\section{Conclusion:-}

It is very important and necessary to compile a cadaster of industrial wastes reflecting their quality, physic-chemical and mechanical properties, concentrations of basic metals and alloying elements, norms and tailings from various categories of mining enterprises.

Building the concentrator near the quarry must be carried out to improve the production technology of alunite, the primary enrichment of alunite. While obtaining alunite concentrate, it will be necessary to allocate about half of the processing volume to wastes with associated minerals as kaolinite for the further production of refractories, natural building materials and raw materials for faience industry in Ganja.

\section{References:-}

1. Afandiyeva Z.J. 2017. Mineral raw materials resources of Azerbaijan and their development problems in modern conditions. VII International Scientific and Practical Conference. World science problems and innovations. 363-366

2. Afandiyeva Z.J. 2014. The impact of mining on the environment. Mining Institute of Ural Branch Russian Academician of Sciences. Web-periodical scientific publication. The second edition.166-168

3. Afandiyeva Z.J. 2016. Complex development problem of ores and overburden. 15th International Conference, Resource-reproducing, low-waste and environmental technologies for subsoil development.169-171

4. Bradley C., Sharpe A. A. 2009. Detailed analysis of the performance of mining in Canada / Center for the study of living standards. 434.

5. Chanturia V.A. 1995. The main directions of complex processing of mineral raw materials. Mining journal. N1.50-54.

6. Geology of Azerbaijan. 2003. Volume VI "Minerals".576.

7. Geology and Mineral Resources of Azerbaijan 2000. 216.

8. Gashgay M.A. 1970. Alunite, its genesis and use.400.

9. Khalifazada C.M., Mamedov I.A. 2011. Ecological aspects of mining and remaking ores of black metals in Azerbaijan. Abstract of papers. International symposium. 161-180

10. Knysh V.A., Nevskaya M.A. 2015.Efficient management of mining waste as a condition of rational neprodovolstvenny. Theory and practice of service: economy, social sphere, technologies. N. 4 (26). 39-43.

11. Krasnov O.S., Salikhov V.A. 2014. Encourage the extraction of valuable non-ferrous and rare metals from ash slag waste of coal accumulated at the energy enterprises of the Kemerovo region. N.1. 299-303

12. Larichkin F.D. 2000.Methodical features of economic efficiency assessment of the complex use of raw materials. N2. 92-99.

13. Mineral resources of Azerbaijan2005. 807.

14. Nabiyev N.A. 1978. Complex use problems of mineral resources. Azerbaijan. 256.

15. Nevskaya M.A. 2013.The main problems of waste management of mining and processing of mineral resources/ "Actual problems of economics and management" Collection of articles of the First Corresponding Scientific and Practical Conference. 84-91. 
16. Pevzner M.E. 2001. Mining and environmental protection.300

17. Trubetski K.I., Galchenko Y.P. Burtsev L.I. 2003. Ecological problems of subsoil development in the sustainable development of nature and society.261. 